\title{
Bride Price and Sexual and Reproductive Rights of Women: A Case Study of South Africa and Nigeria
}

\author{
Bolanle Oluwakemi Eniola,PhD ${ }^{1 *}$ Joseph. I. Aremo, $\mathrm{PhD}^{2}$ \\ 1.Faculty of Law, Ekiti State University, Ekiti State University, P.M.B 5363, Ado -Ekiti, Nigeria \\ 2.Former Commissioner, Ondo State Law Commission and currently Lecturer, Joseph Ayo Babalola University, \\ Ikeji, Osun State, Nigeria
}

\begin{abstract}
This paper studies the effect of bride price on the realisation of the sexual and reproductive health rights of women in South Africa and Nigeria. It adopts the doctrinal research method by reviewing the nature and form of bride price in South Africa and Nigeria. The paper also considers the legal framework for sexual and reproductive health rights of women in South Africa and Nigeria and the consequential effects of bride price on the sexual and reproductive health rights of women in the two countries. It argues that the payment of bride price inhibits the realisation of the sexual and reproductive health rights of women entrenched in various international instruments which both South Africa and Nigeria are signatories and their respective domestic laws. The paper submits that men in the society should be educated that the payment of bride price does not translate to buying their wives but as a mere token to show their gratitude in anticipation for the gift of a wife. Payment of bride price should be seen as a mere cultural observation without the ulterior motive of subjugating the woman.
\end{abstract}

Keywords: Bride Price, Women, Sexual Rights, Reproductive Rights, Nigeria, South Africa

DOI: $10.7176 / \mathrm{JLPG} / 96-04$

Publication date: April $30^{\text {th }} 2020$

\section{Introduction}

In most African societies, one of the requirements of a valid customary marriage is the payment of the dowry/bride price. The payment of the bride price of a woman implies quite a number of things, among which are, consolidation of the relationship between the families of the bride and the grooms, enhancement of the value of the woman in the society, it also includes ownership of the woman and her belongings, among others. Consequently, bride price is one of the major factors that entrench gender inequality in Africa. This is because it involves the transfer of the right in the woman to her husband.

A woman whose parent received her bride price does not have absolute control over her body anymore. From the moment, when the families conclude the transaction, her rights, presumably, subsumed in the husband. This promotes domination of women by men; it gives the impression that women are mere chattels, articles, or property for purchase and not human beings with rights and dignity. It is evident from the foregoing that bride price could inhibit the sexual and the reproductive health rights of women; women, who married under the customary law, might not be able to exercise their sexual and reproductive autonomy. It is in the light of this, that this paper evaluates the implication of bride price on the sexual and reproductive health rights of women in South Africa and Nigeria.

\section{An Overview of the Nature and Form of Bride Price in South Africa and Nigeria}

South Africa and Nigeria are multi-cultural societies with different ethnic groups. This is evident in Section 6 of the South African Constitution, which recognizes eleven official languages. Even though English is the only official language recognized in Nigeria, Nigeria has about over 250 ethnic groups. The implication of the foregoing is that what bride price constitutes varies from one ethnic group to another. Customary law varies from one ethic group to another, even within an ethnic group the customary law may not be out rightly the same. Notwithstanding the variations, the cultures in most parts of Nigeria have many similarities. According to Kasumu and Salacuse,

Although the customary rules on a particular point may vary in detail from tribe to tribe, one

finds nevertheless, that a common thread of similar basic concepts and principles seems to run throughout most, if not all of Nigeria's customary law systems ${ }^{1}$.

In Nigeria, different cultures use the terms 'dowry' and 'bride price' interchangeably. Scholars have argued that the use of the word 'dowry' as a consideration for a marriage contract is confusing: in Europe and other countries, it refers to the property, which a woman brings to her marriage. ${ }^{2}$

The pronouncement of Oki J, in Ibikade v Aize, is profound on the distinction between dowry and bride price. He said:

$$
\text { Is the term 'dowry' equivalent to the term price? Or 'purchase price' of an }
$$

\footnotetext{
${ }^{1}$ AB Kasunmu and JW Salacuse , Nigerian Family Law ( Butterworths, London, 1966)16-17

${ }^{2}$ EI Nwogugu, Family law in Nigeria ( Heinemann, Nigeria, 1974) 44.
} 
article... Dowry on the other hand is not usually a single of or simple sum like a price. Dowry in a customary law marriage is the total of various necessary sums or fees which must be paid by the prospective husband either at different stages and/ or for different heads or purposes to seal the marriage agreement between the parties and their families... ${ }^{1}$

In the traditional Nigerian setting in most of the societies, the dowry consists of the labour rendered by a man to the parent of the woman he sought to marry. Likewise, the bride price did not depict monetary payment - but rather labour provided by a man to assist the parent of a woman he has shown interest in marrying. Such assistance included farm work, building mud huts, splitting firewood, fetching water, or collecting palm fruits. In some cases, prospective in-laws may include gifts such as food items and fruits like kolanuts and alligator pepper. The prospective groom and his family members, offer this to show gratitude - in anticipation of the gift of a wife.

However, modernisation has changed this practice, and labour has become monetised. Industrialisation has resulted in rural-urban migration. Most people no longer live in villages and do not engage in farm work; hence the monetization of some of these activities. The payment of a token amount of money, usually decided by the family of the bride, has replaced labour as an acknowledgement of a pending marital relationship between two families. ${ }^{2}$ In the contemporary Yoruba society in the South West Nigeria, for instance, gifts such as food items, drinks, palm oil, and a token as the bride price, have replaced traditional labour services. This is fundamental to the validity of a customary marriage in Nigeria. A woman whose family has not received such gifts is not accorded due respect. In some communities, the amount of cash and other items measured the value of a woman. ${ }^{3}$ The gifts elevate the value attached to her as both a person and a wife. ${ }^{4}$

While the Yoruba culture attached less importance to the monetary aspect of the bride price/dowry, the modern- practice is the refund of the bride price during the customary marriage. The situation is different among the Igbo culture in South East Nigeria, where families placed greater values on the girl child and the marriage ceremony because of the high bride price. The society considers any man that marries a girl from this part of the country as a real man - because such marriage would have depleted his financial resources. ${ }^{5}$ Included in the list of items for the engagement is a specific bride price as one of the items the prospective groom should bring to the customary marriage. This is to ensure that he is willing and capable of taking their daughter as his wife. At the customary marriage, the father of the bride, or her guardian, collects the envelope containing the bride price, and ensures that it complies with the demand.

Equally, in South Africa, bride price or bride wealth is the consideration, in terms of goods or money, given by the groom's family to the bride's family in a customary marriage. Each of the diverse cultural groups in South Africa has different names for bride wealth. In Zulu, it is lobola, while the Xhosa equivalent is $i k h a z i$; the Tswana call it bogadi, the Southern Sotho refer to it as bohali, among the Tsonga, it is lovono and the Venda refer to it as thaka. ${ }^{6}$ This paper use the term lobola to denote pride price because it is used more widely in South Africa.

Lobola is defined as "cattle or other property which, in consideration of an intended customary or civil marriage, the intended husband, his parent or guardian or other person agrees to deliver to the parent or guardian of the intended wife."7 It is a "property in cash or kind ... which a prospective husband or the head of his family undertakes to give the head of the prospective wife's family in consideration for a customary marriage." 8

Thus, lobola consists of a significant gift in the form of money or cattle from the groom and his family - to the father of the bride. ${ }^{9}$ The groom's family might decide not to pay Lobola in full at once as long as there is an agreement that the family of the groom would eventually complete its payment later. ${ }^{10}$ In Maloba v Dube, the court held,

It is trite African customary law that there is no rigid custom governing the time stipulation within which lobola has to be fully paid. What is sacrosanct is the undertaking to pay the agreed lobola..."11

The bride's family reciprocates this gesture with feasting and a show of great hospitality (umaho).

Because customary marriage transcends the relationships between the husband and the wife, the two families are always involved in the marriage negotiations. The prospective groom's parents, particularly his father/guardian,

\footnotetext{
${ }^{1}$ [1974] 4 U.I.L.R 18

${ }^{2}$ A Emiola, The Principles of African Customary Law (2 $2^{\text {nd }}$ edn, Emiola Publishers, 2005) 102-103

${ }^{3}$ OM Adefi, 'Cultural Practices and Traditional Beliefs as Impediments to the Enjoyment of Women's Rights inNigeria'[2009] 1 JCLI118, 123.

${ }^{4}$ A Emiola, op. cit 103 .

${ }^{5}$ Adefi, op. cit 123

${ }^{6}$ TW Bennett, Human Rights and African Customary Law (Cape Town, Juta, 1999) 220-242.

${ }^{7}$ Section 1(1) of the Codes of Zulu Law.

${ }^{8}$ Section 1(iv) of the Recognition of Customary Marriages Act 120 of 1998.

9 A. Meyer-Weitz et al, "The socio-cultural contexts of sexually transmitted diseases in South Africa: Implications for education programmes ' [1998] 10(2)AIDS Care: Psychological and Socio-Medical Aspects of AIDS/HIV 35,41.

${ }^{10}$ Southon v Moropane[14295/10] [2012] ZAWCHC 31 Para 82

${ }^{11}$ Maloba v Dube [2008] ZAGHPHC 434 at Para 24
} 
negotiate with the prospective wife's parents/guardian. The bride's father has the authority to prevent or delay the marriage by refusing the bridewealth - or he may accept a more attractive bridewealth from another suitor. ${ }^{1}$ The negotiations between the parents of the prospective couple culminate in their consent to the marriage. The woman does not interfere in marriage arrangements because, customarily, she is a 'perpetual minor'. ${ }^{2}$

From this comparative analysis of what bride price symbolizes in South Africa and Nigeria, the payment of bride price suggests a number of things. The next section proceeds with their discussion.

\subsection{Legitimation of the Customary Marriage}

The payment of the bride price customarily legitimizes the marriage between the couple. Marriage in traditional African society is not just between the couple; it involves their immediate and extended family members. The negotiation and payment of the bride price is a medium for bonding between the two families. This is evident in the fact that the South African culture permits payment of lobola by installments.

The bride's family expects the first payment before the marriage and the rest after the birth of a child. ${ }^{3}$ The belief is that this would create a relationship between the two families, which transcends the death of either partner. In addition to this, payment of lobola also helps to stabilise the marriage, as the husband may lose his lobola if he ill-treats his wife. In the same vein, the bride considers the payment of lobola by her husband as a sign of commitment and love. In the same vein in Nigeria, the payment of the bride price is one of the conditions precedents to a valid customary marry. Its payment gives legitimacy to the union of the couple.

\subsection{Acquiring right over the children of the marriage by the husband}

Payment of bride price reinforces African patriarchal systems, in which the man dominates and dictates whatever happens in the family. The implication of this is that children born by the woman belongs to the husband. This entitles the children of such union the right to bear the husband's family name. Children, whose fathers' defaults in the payment of lobola are, by customary recognition, illegitimate. Consequently, couples still abide by the practice, even if they have contracted civil marriages. ${ }^{4}$ Black South African men consider the payment of lobola as their "cultural duty"; it gives them a sense of pride, as it proves that they can financially support their new home. ${ }^{5}$

Equally, in Nigeria, bride price gives paternity to the children of the marriage. The court declined this position in the case of Edet $v$ Esien $^{6}$ because the woman was cohabiting with the natural father of the child. In the case of dissolution of customary marriages in Nigeria, the husband takes custody of the children because culturally, the children belong to the husband exclusively.

2.3 The woman is seen and treated like a chattel: In most cases, her buyer, the husband and his family, who paid the bride price, treats a woman like a chattel. In addition, all her rights from the point of payment of the bride price subsumed in the husband, who reserves the unequivocal right to deal with her as he likes. The payment of bride price is a major source of exploitation by the husband and the in-laws. ${ }^{7}$

2.4 Symbol of a woman's value: Bride price proves the worth of a woman and gives her a sense of pride - both within her immediate family and the community at large. In South Africa, the status of the bride's father in the community determines the number of cattle the prospective groom would pay. The bride's personal virtue (her virginity) and her educational status also determine the amount of the lobola. ${ }^{8}$

2.5 Compensation for money used in training the girl: Bride price in contemporary South Africa and Nigeria is now a monetized commodity. In South Africa, money and gifts have replaced cattle. ${ }^{9}$ Thus, groom can pay the monetary value of the expected cattle for lobola. Furthermore, due to its economic value, there is a constant increase of lobola ${ }^{10}$ It is now regarded as a form of compensation to the bride's family, for what they spent on their daughter before marriage. This may suggest that the parents are selling their daughter - thereby violating her reproductive health rights. ${ }^{11}$ It is also a violation, of the woman's right to dignity, as the husband may consider the

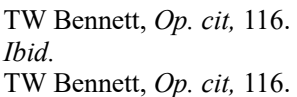

${ }^{4}$ S Gustafsson \& SY Worku, 'Marriage Markets and Single Motherhood in South Africa'[2006] Tinbergen Institute Discussion paper, No.06Ibid 102/3, 10 Available at http://hdl.handle.net/10419/86260 Accessed on 24th March,2020

${ }^{6}$ [1932] 11 NLR , 47

7 IP Enemo, 'Legal Implications of “ Bride Price” or " Dowry" on Women's Human Rights in Nigeria' in J N Ezeilo and JE Alumanah (eds), Bride Price and the Implications for Women's Rights in Nigeria (WACOL,2008) 35

${ }^{8} \mathrm{TW}$ Bennett, Op.cit, 226.

${ }^{9}$ AF Steyn \& CM Rip, ‘ The Changing Urban Bantu Family’ [1968] Journal of Marriage and Family 508.

${ }^{10}$ TW Bennett, Op.cit, 223.

${ }^{11}$ AF Steyn \& CM Rip, Op.cit 
wife to be a commodity that he purchased, and which must yield interest through procreation. In this type of situation, it may be difficult for the woman to exercise reproductive autonomy.

Payment of a bride price affects a woman's dignity. A woman whose husband has spent a fortune to marry her - is under an obligation to reciprocate by bearing as many children as possible. If she fails to do so, she is tagged a failed woman, and this is a good ground to end the marriage.

\section{The Legal Framework for Sexual and Reproductive Health Rights of Women in South Africa and Nigeria} Sexual and reproductive health rights $(\mathrm{SRH})$ are derivatives of the rights recognised in international and regional human rights treaties, declarations and other instruments. These include the International Covenant on Economic, Social and Cultural Rights (ICESCR), ${ }^{1}$ the UN Convention on the Elimination of All Forms of Discrimination against Women (CEDAW), ${ }^{2}$ the UN Convention on the Rights of the Child (CRC), ${ }^{3}$ the International Convention on the Elimination of all Forms of Racial Discrimination. ${ }^{4}$

Sexual and reproductive health are among the most sensitive and controversial issues in international human rights law, but they are also among the most important issues. ${ }^{5}$ To comply with international human rights standards, SRH services have to be available, accessible, acceptable and of good quality. ${ }^{6}$ Judicial redress and remedies should also be available for victims of violations of sexual and reproductive health rights. The recognition of these rights has an indispensable role to play in relation to the attainment of the highest level of complete physical and mental health. ${ }^{7}$ Some specific rights, already existing in international human rights instruments relevant to SRH, are the right to the highest attainable standard of health; right to life and survival; autonomy and confidentiality; information and education; equality and non-discrimination; and the right of women to have control over and decide freely and responsibly on matters related to their sexuality, including sexual and reproductive health, free of coercion, discrimination and violence. ${ }^{8}$ By extension, sexual and reproductive rights include the right to exercise control over one's body, such as the right to choose whether, when, where, and with whom to have sex. It also includes the right of access to modern family-planning methods; the right to maternal, new-born and child health-care services; the right to safe, legal and accessible abortion services; freedom from gender-based violence and the right to appropriate medical, counselling and legal services; and the right of access to sexual education and information. ${ }^{9}$

\section{SOUTH AFRICA}

In South Africa, sexual and reproductive health rights assumed its significance from the recognition of the right to health. Section 27(1) (a) of the Constitution of the Republic of South Africa, 1996 (1996 Constitution) provides that "everyone has the right to have access to health care services, including reproductive health care." This right allows women to have the freedom to decide if and when to begin a family and the right to be informed of and to have access, if they choose, to safe, effective, affordable, and acceptable family planning. ${ }^{10}$ Other rights that relate to sexual and reproductive rights of women guaranteed by the 1996 Constitution include rights to equality, ${ }^{11}$ human dignity, ${ }^{12}$ life, ${ }^{13}$ privacy, ${ }^{14}$ education, ${ }^{15}$ and bodily and psychological integrity. ${ }^{16}$ Section $12(2)$ provides that citizen has the right to bodily and psychological integrity, which includes the right to make decisions concerning reproduction; and to security in and control over their body.

There are other laws enacted in line with the rights guaranteed by the 1996 Constitution. For instance, the Choice on Termination of Pregnancy Act (CTPA $)^{17}$ has broad provisions relating to the termination of pregnancy.

${ }^{1}$ Adopted by the UN General Assembly resolution 2200A of $16^{\text {th }}$ December, 1966.

${ }^{2}$ Adopted by the UN General Assembly resolution 3180 of $18^{\text {th }}$ December, 1979.

${ }^{3}$ Adopted by UN General Assembly resolution 44/25 of $20^{\text {th }}$ November, 1989.

${ }^{4}$ Adopted by UN General Assembly resolution 2106(XX) of $21^{\text {st }}$ December, 1965.

${ }^{5} \mathrm{P}$ Hunt\& J Bueno De Mesquita, The Rights to Sexual and Reproductive Health Essex: Human Rights Centre (2006) available at http://repository.essex.ac.uk/9718/1/right-sexual-reproductive-health.pdf accessed on $2^{\text {nd }}$ January, 2020.

${ }^{6}$ UNFPA Sexual and Reproductive Health available at https://www.unfpa.org/sexual-reproductive-healthaccessed on $26^{\text {th }}$ December, 2019.

${ }^{7}$ P Hunt\& J Bueno De Mesquita, Op.cit

8 Amnesty International USA 'Sexual and Reproductive Health Right' available athttps://www.amnestyusa.org/pdfs/SexualReproductiveRightsFactSheet.pdf accessed on $29^{\text {th }}$ December, 2019; United Nations Population Fund (UNFPA)Frameworks and Policies on Sexual and Reproductive Health Gender, October 2009 available at https://www.unfpa.org/sites/default/files/jahia-events/webdav/site/global/shared/documents/events/2009/policies_frameworks.pdf accessed $9^{\text {th }}$ January, 2019.

${ }^{9}$ JC Mubangizi, 'An Assessment of the Constitutional, Legislative and Judicial Measures against Harmful Cultural Practices that Violate Sexual and Reproductive Rights of Women in South Africa' [2015] 16(3) Journal of International Women's Studies 162.

${ }^{10} \mathrm{Ibid}$ at 166

${ }^{11}$ Section 9 of the 1996 Constitution.

${ }^{12}$ Section 10 of the 1996 Constitution.

${ }^{13}$ Section 11 of the 1996 Constitution.

${ }^{14}$ Section 14 of the 1996 Constitution.

${ }^{15}$ Section 29 of the 1996 Constitution.

${ }^{16}$ Section 12(2) of the 1996 Constitution.

${ }^{17}$ No 92 of 1996 , 
According to section 2 of the Act, a woman can terminate a pregnancy in the first 12 weeks, without giving any reason for such. Between 13 and 20 weeks of pregnancy, the law permits her to terminate the pregnancy based on the following opinions of the medical practitioner. If the continued pregnancy would pose a risk of injury to the woman's physical or mental health, or there exists a substantial risk that the fetus would suffer from a severe physical or mental abnormality; or the pregnancy resulted from rape or incest; or the continued pregnancy would significantly affect the social or economic circumstances of the woman. ${ }^{1}$

This suggests that the woman's right is only limited as the pregnancy advances. The CTPA guarantees one of the tenets of reproductive rights, which is the right of "individuals to decide freely and responsibly the number, spacing, and timing of their children and to have the information and means to do so, and the right to attain the highest standard of sexual and reproductive health. It also includes their right to make decisions concerning reproduction free of discrimination, coercion, and violence." 2 The Christian Lawyers Association challenged the constitutionality of the CTPA in Christian Lawyers Association v National Minister of Health and Others ${ }^{3}$. The court found that the fundamental right to individual self-determination "lies at the very heart and base of the constitutional right" to terminate a pregnancy, and that sections 10, 12(2)(a) and (b), 14, and 27(1)(a) provide the foundation for the right to terminate a pregnancy. ${ }^{4}$ The court has, therefore, validates the provisions of the Act.

The National Health Act (NHA) ${ }^{5}$ is another law, which recognizes and promotes the reproductive rights of women. Section 4(3) provides that subject to any condition prescribed by the Minister, the State, clinics, and community health centers funded by the State must provide pregnant and lactating women and children below the age of six years, who are not members or beneficiaries of medical aid schemes, with free health services. This section implies that pregnant and lactating mothers have access to free healthcare services in South Africa. Section 4 also provides free termination of pregnancy services to women, subject to the CTPA. This Act, therefore, supports the CTPA and respects the reproductive autonomy of women.

The Criminal Law (Sexual Offences and Related Matters) Amendment Act ${ }^{6}$ protects sexual rights as it criminalises acts, which interfere with the enjoyment of the sexual rights. Some of the rights linked to sexual rights which the Act protects include the right of all persons, free of coercion, discrimination and violence, to respect for bodily integrity; decide to be sexually active or not; consensual sexual relations; and pursue a satisfying, safe and pleasurable sexual life, among others. ${ }^{7}$ The Act protects these rights by criminalising various sexual offences including rape,${ }^{8}$ and sexual assault, ${ }^{9}$ among others. The above is an indication that South Africa has a progressive body of laws for protecting the sexual and reproductive rights of women.

\section{NIGERIA}

The laws and policies for the protection of sexual and reproductive rights of Nigerian women and girls are in various statutes, service rules and regulations, case laws, general orders, customary law, the Constitution and ratified international treaties and conventions. ${ }^{10}$ In Nigeria, there is no direct platform for the enforcement of SRH rights. The Constitution of the Federal Republic of Nigeria, 1999 (1999 Constitution) does not make express provisions for the right to health as a fundamental right. ${ }^{11}$ Thus, the right gets its recognition under other human rights such as right to life, ${ }^{12}$ respect for dignity of person, ${ }^{13}$ right to personal liberty ${ }^{14}$ and right to privacy. ${ }^{15}$ Section 17(3) (d) of the 1999 Constitution provides that the State shall direct its policy in ensuring that there are adequate medical and health facilities for all persons.

While this provision can accommodate SRH services such services cannot be enforced as, the provisions of Chapter Two of the 1999 Constitution, which contains the Fundamental Objectives and Directive Principles of

\footnotetext{
${ }^{1}$ Section 2 of the Choice on Termination of Pregnancy Act.

${ }^{2}$ Paragraph 7.3 Programme of Action adopted at the International Conference on Population and Development, Cairo, $5^{\text {th }}-13^{\text {th }}$ September, 1994 . ${ }^{3} 1998(4)$ SA $1113(\mathrm{~T})$

${ }^{4} \mathrm{C}$ Pickles, 'Termination of Pregnancy Rights and Foetal Interests in Continued Existence in South Africa: The Choice on Termination of Pregnancy Act 92 of 1996’ [2012] 15(2) PELJ413.

${ }^{5}$ Act 16 of 2003

${ }^{6}$ Act 32 of 2007 .

7“Defining Sexual Health" Report of a technical consultation on sexual health 28-31 January 2002, Geneva World Health Organisation 2006 available at www.who.int/reproductivehealth/publications/sexual health/defining sexual health.pdf accessed on $15^{\text {th }} \mathrm{January}, 2020$.

${ }^{8}$ Section 3 of the SOA provides that "any person ('A') who unlawfully and intentionally commits an act of sexual penetration with a complainant ('B'), without the consent of $\mathrm{B}$, is guilty of the offence of rape."

${ }^{9}$ Section 5 of the SOA provides that A person ('A') who unlawfully and intentionally sexually violates a complainant ('B'), without the consent of $\mathrm{B}$, is guilty of the offence of sexual assault

${ }^{10} \mathrm{O}$ Gbadamosi, Reproductive Health and Rights (African Perspectives and Legal Issues in Nigeria (Benin City: Ethiope Publishing Corporation, 2007) 54

${ }^{11}$ Chapter IV 1999 Constitution.

${ }^{12}$ Section 33 of the 1999 Constitution.

${ }^{13}$ Section 34 of the 1999 Constitution.

${ }^{14}$ Section 35 of the 1999 Constitution.

${ }^{15}$ Section 37 of the 1999 Constitution.
} 
state policy, are not justiciable. ${ }^{1}$ There are, however, various policies introduced by the government to promote sexual and reproductive rights. For instance, in 2001, the Nigerian government, through the Federal Ministry of Health, developed a National Reproductive Health Policy (NRHP)

to provide the necessary guidance and framework for the promotion and implementation of reproductive health programmes and activities. The ultimate aim of this policy is to serve as an effective national platform for strengthening reproductive health activities in Nigeria and facilitating the achievement of relevant global and regional goals in the interest of improved health, well-being, and overall quality of lives of all peoples in Nigeria. ${ }^{2}$

The Africa region vision, according to the NRHP, is that within the next twenty-five years, all people of the region should enjoy an improved quality of life through a significant reduction of maternal and neonatal morbidity and mortality, unwanted pregnancy and sexually transmitted infections including mother-to-child transmission of $\mathrm{HIV}$, and through the elimination of harmful practices and sexual violence. The country is however yet to provide enforcement mechanisms for the effectiveness of this policy.

It is important to note that in Nigeria, there is a restriction on termination of pregnancy. By virtue of the Criminal Code Act, ${ }^{3}$ which is applicable in Southern Nigeria, and the Penal Code Act, ${ }^{4}$ which is applicable in Northern Nigeria, the law only permits termination of pregnancy to preserve the life of the mother. Section 297 of the Criminal Code provides that a person is not criminally responsible for performing in good faith and with reasonable care and skill a surgical operation upon any person for his benefit, or upon an unborn child for the preservation of the mother's life, if the performance of the operation is reasonable, having regard to the patient's state at the time and to all the circumstances of the case. ${ }^{5}$ This limits the right to reproductive autonomy of a woman, as the law does not allow her to terminate pregnancy no matter what stage the pregnancy is.

Some provisions of the Criminal Code and the Penal Code also protect Sexual rights. Some of the sexual offences covered by these Codes include rape, ${ }^{6}$ indecent assault, ${ }^{7}$ and abduction, among others. ${ }^{8}$ While South Africa has gone a long way in implementing its obligations under the various international, regional, and subregional instruments, Nigeria still has a lot do in this respect. This is because the concept of sexual and reproductive right is wider than existing provisions in the laws. In addition, the laws currently in place need serious overhaul in order to meet international best practices.

\section{Consequential Effects of Bride Price on the Sexual And Reproductive Health Rights of Women in South Africa and Nigeria}

Payment of bride price has many consequential effects on the sexual and reproductive health rights of women. This section discusses some of the effects.

\subsection{Sexual Violence and Marital rape}

The payment of bride price could infringe on the right to bodily and self-determination. This is because bride price reduces women to the status of property and exposes them to all sorts of abuse and health risk.

A wife, on whose head bride price has been paid, does not take part in important family decisions, and these include decisions even concerning her. In the area of reproductive health, she has no say, yet she has rights. She has no say on when and when not to engage in sexual intercourse with her husband. She will not participate in any decision about child bearing; neither can she negotiate the use of contraceptives. ${ }^{9}$

The implication of the foregoing is that the bride price gives the husband the license to deal with the wife's body, as he likes. Because of this, the husband can assault the wife sexually, as he could demand for sex even when it is not convenient for the wife; he could even rape her. He will justify his action by the fact that he cannot violate the body of the wife, as she is his personal property.

In addition to this, the woman cannot ask her partner to use protection, even when she suspects that he is unfaithful. The husband would object to, for instance, the idea of using a condom, and retort, "that bride price was paid in full and no discount was given to make up for the use of condom" 10 . In this situation, the woman might be

\footnotetext{
${ }^{1}$ See Section 6(6)(c) of the 1999 Constitution.

${ }^{2}$ Federal Ministry of Health 'National Reproductive Health Policy and Strategy to achieve quality reproductive and sexual health for all Nigerians' 2001, Foreword.

${ }^{3}$ Cap C38, Laws of the Federation of Nigeria, 2004

${ }^{4}$ Cap 3-1, Laws of the Federation of Nigeria, 2004.

${ }^{5}$ See also section 232 of the Penal Code.

${ }^{6}$ Section 357 of the Criminal Code and section 282 of the Penal Code.

${ }^{7}$ Section 360 of the Criminal Code.

${ }^{8}$ Section 361 and 362 of the Criminal Code.

${ }^{9}$ IP Enemo, Op.cit 36

${ }^{10} \mathrm{NG}$ Onyeneho, 'Reproductive Health Rights and Behaviour of Mbaise Women: The Bride Price Factor' in JN Ezeilo and JE Alumanah (eds),
} 
prone to contact human immuno-deficiency virus/ acquired immune deficiency syndrome (HIV/AIDS) and other sexually transmitted diseases.

\subsection{Maternal mortality and morbidity}

One of the effects of the payment of bride price is the subjugation of the sexual and reproductive rights of the woman. Because of this, she would not be able to decide on the spacing of the children and the number of children she desires. Not being able to control the number of children and the intervals between their births is detrimental to the health of the woman. It could even lead to death. A woman whose husband is displeased with the exorbitant bride price taken from him or has been drained financially might not receive adequate care during pregnancy due to financial constraint. The husband might even be frustrated and transfer his aggression to his wife, which could lead to physical abuse during pregnancy. This could lead to miscarriage, abortion, and even death.

As noted by Bennet, in South Africa, the effect of lobola on the marriage contract is that the husband and his family take ownership of the bride, and any offspring of the marriage. ${ }^{1}$ This is because men could interpret the payment of lobola as a licence to take authority over the bride's body. ${ }^{2}$ The payment of lobola is regarded as a neutral medium in exchange for woman's reproductive ability. ${ }^{3}$ Consequently, she does not have a say as to the number of children she will have during the marriage. ${ }^{4}$ Thus, payment of lobola represents a consideration in anticipation of what the wife is going to produce, and the value (regarding the number of children) she is going to add to the family. ${ }^{5}$ In traditional black South African society, the use of cattle for the payment of lobola symbolised reproduction.

4.3 Child marriage: The culture in both South Africa and Nigeria encourages early/forced marriage. The Islamic religion, mostly practiced in the northern part of Nigeria, influences child marriage while ukuthwala is the South African version of early / forced marriage. Parents facing economic challenges see marriage as a way of relinquishing their financial responsibilities to the husbands of their daughters. For such parents, a girl child is a means of enhancing the family's financial status. The payment of bride price/dowry by the prospective groom is more important than her education. Such parents would not enroll the girls in school because of the erroneous belief that education is of no use to them. In cases where they do attend school, as soon as the parents identify a suitor, they would withdraw the girl child from school, and got her married off. ${ }^{6}$

Child marriage has negative reproductive consequences, which include teenage pregnancies, teenage motherhood, and psychological trauma. Because her body is not physiologically ready for motherhood, the young girl might experience recurrent urinary tract infections, sexual dysfunction, chronic pelvic infections, prolonged obstructed labour, and vesico-vaginal and recto-vaginal fistulae (VVF and RVF). This occurs when the cervix is not fully developed; the pelvic bones do allow the easy passage of the child, and consequently, the young girl begins to lose urine uncontrollably from the vagina. ${ }^{7}$ This disease is very common in northern Nigeria that has the highest prevalence of girl child marriage. In Jigawa state, for instance, $64.1 \%$ of girl children are married off at an early age, while the figures for Kaduna, Benue, Yobe and Kebbi are 58.9\%, 54.5\%, 47.6\% and 54.1\%, respectively. ${ }^{8}$

Medically, young girls are susceptible to complications during pregnancy because their reproductive organs might not be fully developed. ${ }^{9}$ The UNFPA notes that females between the ages of 15 and 19 are twice more likely to die at child birth than those in their 20s. Furthermore, females younger than 15, are five times more likely to die than those in their $20 \mathrm{~s}^{10}$. If they are victims of sexual relationship by coercion, with a man whose health status is unknown to them, they are susceptible to HIV and other sexually transmitted diseases. .All these factors endanger the life of the young bride.

Furthermore, marriage carries responsibilities that are beyond a young girl's capacity. The expected result of marriage in most African societies is procreation; the young bride will be burdened with child bearing and rearing, as well as housekeeping. Early marriage will also adversely affect her social development. The age difference between the abducted girl and her abductor means that such a relationship involves subjugation. It may also involve rape.

Bride Price and the Implications for Women's Rights in Nigeria (WACOL,2008) 97-98

${ }^{1} \mathrm{NG}$ Onyeneho,Op.cit

${ }^{2}$ C Abertyn, 'Contesting Democracy: HIV/AIDS and the Achievement of Gender Equality in South Africa' [2003] 29 (3) Feminist Studies

${ }^{3}$ TW Bennett, Op.cit 222.

${ }^{4}$ A Meyer-Weitz et al, Op.cit

${ }^{5} \mathrm{~S}$ Gustafsson \& SY Worku, Op.cit

6 E Durojaiye et al., 'Harmful cultural practices and gender inequality in Nigeria'[2014] 12(1) Gender and Behaviour, 6169 -6181

O Gbadamosi, Reproductive health and rights (African perspectives and legal issues in Nigeria (Ethiope Publishing Corporation 2007), 293.

${ }^{8}$ Ibid, 292

${ }^{9}$ N.M Nour, 'Child Marriage: a Silent Health and Human Right Issue' [2009]2(1) Reviews in Obstetrics \& Gynecology 51-56

${ }^{10}$ UNFPA, ' Maternal mortality update 2004: delivering in good hands' [2004] 11 


\section{Conclusion}

This paper has shown that the payment of bride price inhibits the realisation of the sexual and reproductive health rights of women entrenched in various International Instruments which both South Africa and Nigeria are signatories and their respective domestic laws. Men continually views bride price as a token, which gives them an edge over the woman. The motivation for this development is the notion that the payment of the bride price connotes buying the bride: "This is a misunderstanding of the legal purpose of 'bride price' in African culture". 1 Men in the society should be educated that the payment of bride price does not translate to buying their wives but as a mere token to show their gratitude in anticipation for the gift of a wife. Hence, the need for the change of the name bride price, in line with the submission of $\mathrm{Onoka}^{2}$, as it is demeaning.

The receipt of marriage symbol by the bride's parent or guardian is not an indication of 'sale' or 'purchase' of their daughter. Rather, the acceptance of it as a further confirmation of their consents. ${ }^{3}$ Culture is not static, it is dynamic, and as such, amenable to modification to ensure that a woman is priceless, and as such, the husband should accord her such treatment. The society should see and treat women as priceless human beings with equal dignity and rights with their men counterparts in marriage. This is possible when the society view bride price as a mere cultural observation without any ulterior motive to subjugate the woman.

\footnotetext{
A Emiola, Op.cit 37.

${ }^{2}$ MC Onoka, Family Law ( Spectrum Books Ltd.,Ibadan, 2003)

${ }^{3}$ Ibid, pp90-92
} 